\title{
Successful Factors of Social Rehabilitation of People Based on Intellectual Disability Group Through Batik Ciprat Business by Bina Grahita Social Rehabilitation Center (BBRSBG) Kartini Temanggung Regency
}

\author{
Ismet Firdaus \\ Social Welfare Study Program \\ Syarif Hidayatullah \\ State Islamic University (UIN) \\ Jakarta, Indonesia \\ ismet.firdaus@uinjkt.ac.id
}

\begin{abstract}
Bina Grahita Social Rehabilitation Center (BBRSBG) Kartini in Temanggung district (under the coordination of Ministry of Social Affairs) initiated a social rehabilitation program through Social Independent Groups (KSM) in the form Batik Ciprat business in 2015. The program aimed at economic independence for people with intellectual disability was successfully implemented by two groups, namely KSM Reksa Darma Bakti in Reksa Sari village, Semarang and KSM Sambung Roso in Simbatan village, Temanggung district. Both KSM were considered successful in implementing social rehabilitation indicated by the economic independence of some intellectual disabilities and shown by several achievement awards. It was noted that the products of Batik Ciprat produced by intellectually disabled people have been marketed in and out of Indonesia (South Korea and Singapore) and have received an award from the Ministry of Administrative and State Bureaucracy Reform. This paper reports a qualitative descriptive research on the success of social rehabilitation program and finds five factors contributing to the success. First, as found by Drs. Ciptono, a teacher at a Disabled School in Semarang, Batik Ciprat has a unique motif which is marketable and also doable by the intellectually disabled people. Second, KSM facilitators succeeded in some stages of rehabilitation namely outreach, assessment, individual and group guidance, training, production assistance and evaluation of economic independence. Third, the active endeavor by the board of BBRSBG Kartika and KSM administrators in marketing Batik Ciprat through exhibition events and social media. Four, the visit of study tours. Five, a policy mandated the use of Batik Ciprat as the uniforms of BBRSBG Kartini staffs in Temanggung district, thus the market segment of this product is stable.
\end{abstract}

Key words : Social Rehabilitation, Social Independent Groups, Batik Ciprat

\section{PRELIMINARY}

Social Rehabilitation in Social Welfare Sciences is a subject of research that always interesting to be studied, because Social Rehabilitation is made a standard for the social worker profession in dealing with social issues as written in the social minister of the Republic of Indonesia Regulation No. 22 of 2014 [1]. One of the social rehabilitation targets contained in the article 5 Regulation of the social minister is a person with disability. Officially the term of disability (kecacatan in Indonesia) has been changed to disability (disabilitas in Indonesia) in line with the issuance of Law No. 8 of 2016 on disability. In Article 17 of the Disability Act, one of the social welfare rights for persons with disabilities is social rehabilitation rights.

The results show that social rehabilitation for persons with disabilities is very important. Syam Fathurrachmanda et. al. (2013, p.ii) [2]show that social rehabilitation applied in accordance with the legislation and regulation of the government in UPT Rehabilitation neutral defect in Malang has made the client better and functioning socially appropriately. Other research shows that social rehabilitation through social guidance of individual, group and society as well as skills guidance from the UPT Social Rehabilitation of East Java Social Service in Pasuruan has been able to provide improved inner, outward and social welfare.

More comprehensively, the Ministry of Social Affairs team evaluated the Social Rehabilitation of disability within the Government House in Indonesia, although it received positive results, but there were some shortcomings or some obstacles faced so that the service became less optimal. For example, the Family becomes the place of origin of the client did not get intervention, so the result becomes less balanced. [3] Including, the absence of involvement of social institutions that recommend the client to obtain services in the orphanage. Thus, the services in the orphanage only focus on the client, not on the client system. In the client system, the service in the orphanage is not only aimed at the client as the focus of the service, but family and community involvement since the child receives 
the service in the orphanage is as important as the treatment on the client.(Nurdin Widodo, et.all : 2012, p.ii) [4]

On the other hand, not only is the study of social rehabilitation important to be studied, but also the Government itself has set the issue of disability as one of the priority issues that need to be addressed. This is stated in Presidential [5]

Regulation No. 2. 2015 on National Medium-Term Development Plan (RPJMN) 2015-2019 written where the Directorate General of Social Rehabilitation has set three priorities of Indonesia [1] namely; 1). Abandonment 2). Disability 3). Social Disappearance. With regard to the handling of disability has undergone a paradigm shift from a charity based approach, to a more forward-looking approach that prioritizes the fulfillment of the rights of persons with a right-based approach. The paradigm shift is inseparable from efforts to handle the number of people with disabilities that tend to increase. According to Susenas's data in 2012, the number of persons with disabilities in Indonesia is 6,008,640 people. Based on data from Susenas in 2012, it is known that Indonesia's population with disability was $2.45 \%$. The number and distribution of persons with Disabilities Percentage of Persons Based on Susenas's in 2003, 2006, 2009 and 2012 as follows [5]

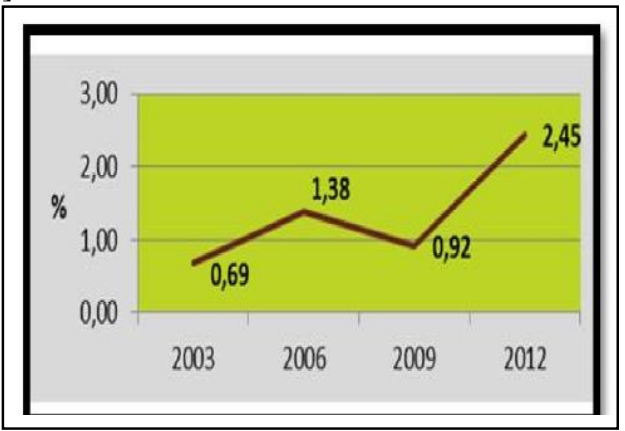

The change of Government paradigm implies the policy and program of the Ministry of Social Affairs. One of the Technical Implementation Unit of the Ministry of Social Affairs that conducts social rehabilitation for PwDs is the Bina Grahita Social Rehab Center (BBRSBG) Kartini located in Temanggung Regency. Bina Grahita Social Rehabilitation Center (BBRSBG) Kartini

Temanggung Ministry of Social Affairs since 2015 had launched a communitybased Disability Rehabilitation program under the name of "caring village" [3]. This caring village is participatory then formed Self-Help Groups (KSM). This KSM is located in 6 locations. However, out of the 6 , the non-governmental groups that are considered successful in carrying out the program are 2, namely; KSM Reksa Darma Bakti [6] , Desa Reksa Sari Kabupaten Semarang and KSM Sambung Roso Desa Simbatan through social rehabilitation program based on KSM with Ciprat batik business done by intellectual disabilities. His batik work has been ordered in and out of the country (South Korea and Singapore) and received an award from the Ministry of Administrative Reform and Bureaucracy Reform.

\section{DEFINITION of SOCIAL REHABILITATION}

Social rehabilitation is the process of refunctionalization and development to enable one to be able to carry out its social functioning fairly in the life of the community. Social Rehabilitation Form (Article 7) Social Rehabilitation is given in the form of psychosocial motivation and diagnosis; care and nurturing; vocational training and entrepreneurship coaching; spiritual mental guidance; physical guidance; social counseling and psychosocial counseling; accessibility services; social assistance and assistance; guidance of resocialization; further guidance; and/or referrals. Stages of Social Rehabilitation (Article 19) [1] Social Rehabilitation is carried out by stages: initial approach; disclosure and understanding of the problem; preparation of problemsolving plans; solution to problem; resocialization; termination; and further guidance. (Goverment Regulations by Ministry of Social Affairs of the Republic of Indonesia, 2014)

\section{KSM REKSA DARMA BAKTI, KABUPATEN SEMARANG and KSM SAMBUNG ROSO KABUPATEN TUMANGGUNG}

In Semarang regency, there are 2 KSM namely KSM Reksa Darma Bakti di Desa Reksasari, Kecamatan Suruh. Where in both villages, the number of population with disability as many as explained by Drs. Mohtarudin, Head of Social Affairs, Department of Social, Manpower and Transmigration of Semarang Regency, in Kabupaten Semarang, the number of people with disability was 7,300 people. Out of these 7,300 people, $60 \%$ (4,380 persons) were physically and sensory disabilities (disability, neutrality, lethargy, speech) and 40\% $(2,920)$ are persons with mental and intellectual disability. These $2 \mathrm{KSMs}$ had social rehabilitation with leading programs productive economy through batik Ciprat.

However, that was successful in KSM Reksasari. Through Assistance by Social Workers in 2016 this program found the result. For example, Batik Ciprat products of intellectual disability in KSM Reksa Darma Bakti Reksasari Village,

Suruh Sub-district, Semarang Regency was growing and able to entered the market. If in 2015 the average order of batik was only 20-30 pieces, entering 2016 increased quite sharply. Since January 2016, batik Ciprat orders from KSM is not less than 50 pieces. Even in March and April, orders reached 130 pieces. In addition to this location many parties to visit, field practice or comparative studies. In the nearest location, almost every guest visit, practice, comparative study and others are directed to Reksasari Village. The impact, product products [3]

KSM Reksa Darma Bakti also increasingly known by the wider. Even from Ministry of Administrative and Bureaucratic Reform RB and KODDI of South Korea also come to cover and visit Kampung Peduli Desa Reksasari. This success adds to the social functioning of the 
intellectual disability in this village. In Magetan district of East Java, a caring village is located in Simbatan, [7]

Nguntoronadi District. The number of people with disabilities at Kecamatan Nguntoronadi are 150 consisted of 39 children and 111 adults. In the village of Simbatan alone the number of people with disability is 19 people. The success of the Swadaya Masyarakat Sambung Roso Desa Simbatan group to bring independence of through the productive economic centre has attracted the attention of various parties [3]. Beginning with the village government providing facilities and allocating village funds, then the Social and Transmigration Office and Nguntoronadi Subdistrict Office which always support through various forms of facilitation (funds, facilities, opportunities, promotion, etc.) succeeded in generating the awareness of various parties to PwDs. The work of batik Ciprat from this intellectual disability by the Magetan District Land Office employee is used as the new blue combination uniform. Local government support Magetan (District Nguntoronadi and Dinsosnakertrans Magetan) also never stop flowing. In the framework of the anniversary of Magetan City, souvenirs for Magetan Regency Anniversary activities are also ordered at KSM Sambung Roso Simbatan. Batik Ciprat Simbatan is expected to be included in Magetan Cultural Icon. [8]

\section{SUCCESSFUL FACTORS of KSM REKA DARMA BAKTI, SEMARANG REGENCY and KSM CONNECT ROSO TUMANGGUNG REGENCY \\ The result of the research shows that there are 5} factors of success of KSM-based Social Rehabilitation at two locations by Bina Grahita Social Rehabilitation Center (BBRSBG) Kartini, Temanggung. First, utilize the findings from Drs. Ciptono, teacher of SLB (school focus on teacher disabilities student or it called Special School in general) in Semarang is batik Ciprat which has unique motif favored by the market and can be done by people with intellectual disability. Secondly, the counselors in the two KSM successfully conducted social rehabilitation from the stage of outreach, assessment, motivation and individual and group guidance, training, assistance in the production process and monitoring and evaluation of the level of economic self-sufficiency. Third, BBSBG Kartika's management and KSM management in marketing through exhibition events of products and social media. Fourth, many visits are conducting comparative studies from within and outside the country. Fifth, the results of this batik Ciprat product became one of the mandatory uniforms of employees of BBRSBG Kartini and civil servant (PNS) in Temanggung, so that the market segment of this product becomes clearer. Sixth, in Magetan, support is not only from the village government to the district, but also from the private sector also promotes batik Ciprat workers with disabilities. [9]

\section{REFERENCES}

[1] Government regulations by Ministry of Social Affairs of the Republic of Indonesia. Indonesia, 2014.

[2] S. Fathurrachmanda, "Implementation of the Social Rehabilitation Program Plan for People with Disabilities (Study at UPT Social Rehabilitation of Blind Disabled in Malang," E-J. Wacana J. Sos. Dan Hum. E, 2013.

[3] Nurcahyo, "skill accompaniment and business development of 'batik Ciprat' at SLB Semarang," J. DIMAS, vol. 15, Oktober 2015.

[4] Widodo Nurdin, "et all, (2012). Abstract, Evaluation of the Implementation of Social Rehabilitation in Social Institutions: Further Development Post Social Rehabilitation," Jakarta: P3KS Press.

[5] "Sub Directorate of Child Social Welfare with Disability Directorate of Child Social Welfare, Directorate General of Social Rehabilitation." Ministry of Social Affairs of the Republic of Indonesia, 2012.

[6] "http://www.kemendagri.go.id/media accessed 28-09-2017," /documents_no mor_8 tahun_2016.pdf.

[7] M. R. Pawening, "efforts to improve the social welfare of persons with disabilities through social rehabilitation" (a study on the technical implementation unit of social rehabilitation of disability in Pasuruan social office of East Java provincial government). Bandung, 2013.

[8] "https://magetankab.bps.go.id," Kabupaten Magetan, Magetan, 2014.

[9] orthose prothese, "Batik Ciprat Order Intellectual Disability Products at KSM Mutual Darma Bakti Increases.," https://kampungpeduli.com,. 